\title{
Research on Content System Constructions in Postgraduate Entrance Education in the New Era*
}

\author{
Ming $\mathrm{He}$ \\ Graduate School \\ Wuhan University of Science and Technology \\ Wuhan, China
}

\begin{abstract}
As "the first class" in the whole process of graduate education, entrance education is an important component of innovation education and talent cultivation for postgraduates, and is also the important content and focus for strengthening the ideological and political education of postgraduates. To exert the leading role of postgraduate entrance education, the paper aims to explore the conventional entrance education activity that "implement entrance adaptive education on the first day, carry out cultivation process education in the first week, launch culture formative education in the first month, develop humanistic motivational education in the first quarter and conduct innovation and entrepreneurship education in the first semester", so as to construct the content system of postgraduate entrance education that adapts to the new era.
\end{abstract}

Keywords—new era; postgraduate entrance education; content system

\section{INTRODUCTION}

Postgraduate entrance education is the focus of the ideological and political education for the postgraduates and plays a key role in the whole process of graduate education. It not only enables freshmen to know the theory of colleges and universities on school management, understand the discipline orientation, and grasp the law of growth and success, but also benefits the freshmen to achieve role transition, build learning objectives and finish school. However, the postgraduate entrance education is usually undertaken by the students' working team, and the teachers only relies on the counselor, class teacher, teachers from department and other personnel to conduct activity, moreover, the theme is only limited to the school rules and principles, enrollment adaptation and other conventional education contents. The subject of education is single and lacks systematicness, qualified teachers is scanty and lacks scientificity, and teaching content is little and lacks hierarchy[1]. Exploring the content system of postgraduate entrance education scientifically is of great significance to deepen the reform of postgraduate education and promote the

*Fund program: "Practice and innovation of iron spirit thematic education and moral education of postgraduates of metallurgy university" of practical education special program of colleges and universities in 2017 in Hubei province (Project No. 2017SJJPC3010); “exploration and practice of the practical education system for full-time professional degree postgraduates" of postgraduate quality engineering project in 2017 of Wuhan University of Science and Technology (Project No. Yjg201722). long-term development of postgraduate education.

\section{THE SIGNIFICANCE OF CONTENT SYSTEM} CONSTRUCTION IN POSTGRADUATE ENTRANCE EDUCATION IN THE NEW ERA

A. Establishing the Content System of Postgraduate Entrance Education in the New Era Is the Important Measure for Colleges and Universities to Promote Socialist Core Values

As the battle position of high-level personnel education and cultivation, the colleges and universities should pay high attention to the initial link of postgraduate education, strengthen the leading role of "the first class" of entrance education, expand the new path of the ideological and political education for the postgraduates, help postgraduates to adapt to the learning life, cultivate the hard-working spirit of the postgraduates, enable postgraduates to form and consolidate the correct outlook on world, life and values, guide postgraduates to become the pioneer, practitioners and inheritors of the socialist core values. In the process of specific implementation, each department should focus on the fundamental task of strengthening moral education and cultivating people, adhere to people-centered education and moral education first, stick to benefitting by mutual discussion and opening new path, and bring socialist core values into the comprehensive planning of postgraduate entrance education. The core values can provide intellectual impetus for the content of entrance education, and the entrance education activity can offer growing environment for the core values, both of which combine closely and supplement each other, so as to cultivate the postgraduates in new era to become the qualified constructer and reliable successor of socialism with Chinese characteristics.

\section{B. Establishing the Content System of Postgraduate Entrance} Education in the New Era Is the Important Measure for Colleges and Universities to Promote Socialist Core Values

The moral education of postgraduates mainly focuses on the education of postgraduates' political tendency, ideological quality and moral accomplishment, as well as the cultivation of nonintellectual factors such as healthy psychology and humanistic care. Improve the ideological and ethical standards 
of postgraduates of colleges and universities and exert the role of entrance education as the primary position, which is conducive to improving the scientific research capacity and humanistic quality of postgraduates so that they will truly become a man of tremendous promise needed by national development. At present, the phenomenon that colleges and universities pay more attention to intellectual development rather than morality still exists, and ideological and political education is slightly weak, and party caucus still remains to be implemented; the colleges and universities usually pay much attention to classroom teaching and scientific research, however, they ignore the cultivation of ideology and morality quality of postgraduates. In the new era, based on the strategic perspective of rejuvenating the country through science and education and strengthening the country through talents, the colleges and universities should cultivate postgraduates to undertake an important business of serving society and building our country, and pay attention to improving the scientific research level of postgraduates, meanwhile, they should greatly enhance the moral education of postgraduates, and cultivate the high-quality inter-disciplinary talents by taking postgraduate entrance education activity as carrier and strengthening the effectiveness of moral education as the objective.

\section{Establishing the Content System of Postgraduate Entrance Education in the New Era Is the Important Measure for Colleges and Universities to Promote Socialist Core Values}

According to different subjects of education, the content of postgraduate entrance education mainly includes: ideal and belief education with the college Party schools as the subject, campus culture education with propaganda department as the subject, professional career education with employment guidance center as the subject, psychological health education with school-based mental health center as the subject, research integrity education with graduate student affairs office of Party committee as the subject, security education with security department as the subject, and a series of thematic education activities involving with red culture experience, university spirit cultivation, schoolmates show, friends demonstration and academic morality observation.[2] These thematic education activities are an indispensable part of campus culture of colleges and universities. The colleges and universities should educate students in the various thematic education activities, edify students when developing campus culture, positively carry out a series of campus culture activities with rich contents, novel form, strong educational value and intense penetration, integrate the entrance education content into the construction of campus culture activity and make the postgraduates be unconsciously influenced by campus culture in the activity. As the spiritual ties of inheriting, developing, communicating and practicing university culture, the campus culture is an effective channel of cultural education and practice education, is the sustain momentum to enhance the effectiveness of postgraduate entrance education, and is the significant carrier to develop moral education practice innovation for postgraduates, and plays an important role in improving the comprehensive quality of postgraduates.

\section{PRACTICAL EXPLORATION OF CONTENT SYSTEM OF POSTGRAdUATE ENTRANCE EDUCATION IN NEW ERA}

The conventional education content in entrance education can be carried out in each department, for example, implement entrance adaptive education on the first day, carry out cultivation process education in the first week, launch culture formative education in the first month, develop humanistic motivational education in the first quarter and conduct innovation and entrepreneurship education in the first semester, which can form a system of conventional entrance education activity of "five in one". (See "Fig. 1") Postgraduates can specifically learn various contents in different stages. Developing entrance education activity with multistage method in the process of professional learning can keep the continuity of educational method and durative of education time.

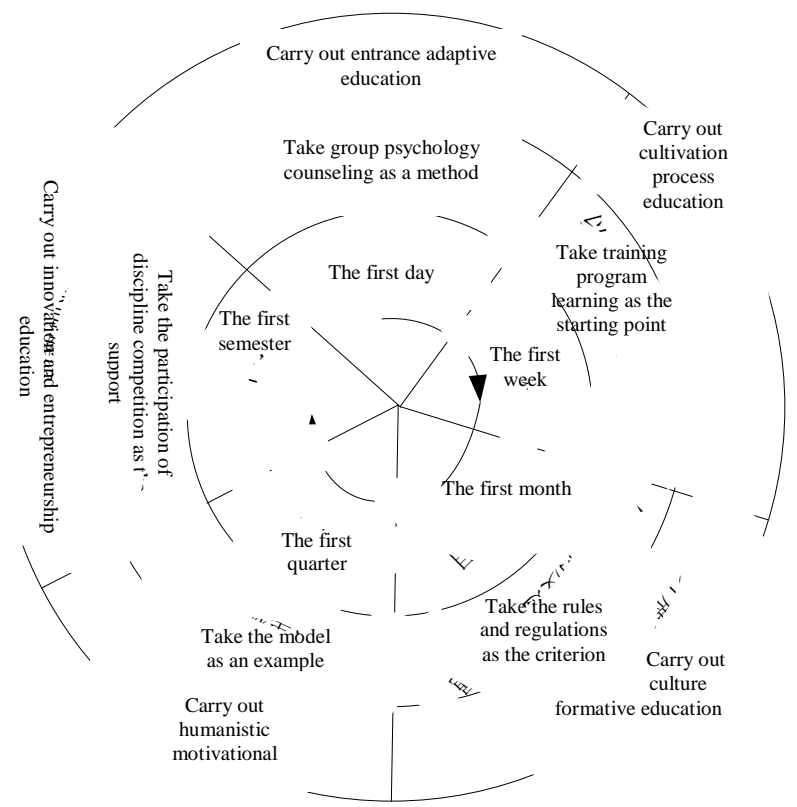

Fig. 1. Content system of postgraduate entrance education.

\section{A. Take Group Psychology Counseling As a Method to Carry out Entrance Adaptive Education}

Group psychology counseling is a kind of psychological counseling and therapy form which provides psychological help and guidance in the context of group. Through the interpersonal interaction within the group, it can help individuals to recognize themselves, probe into themselves and accept themselves, adjust and improve their relationships with others, learn new attitudes and behaviors, so as to develop a good life adaptation process through observation, learning and experience.[3] Group psychology counseling is a new way to cultivate the freshmen's psychological quality, through many group activities, participants can discuss, communicate, probe into the issues of common concern, inspire and encourage each other, observe, analyze and understand their and other psychological and behavioral responses, which is conducive to 
helping them to improve interpersonal relationship, enhancing social adaptation ability and promoting personal growth.

On the first day of postgraduate registration, each department should organize and convene grade meeting and carry out group psychological behavior training for freshmen. This measure not only can enhance group cohesiveness and meet the sense of belonging of postgraduates, but also can create positive scene for postgraduates to learn the method and skill of interpersonal communication and improve the effectiveness of postgraduate entrance education. Developing group psychology counseling can effectively solve the adaptability problem of freshmen and is also an education activity with full of vitality and vigor.

\section{B. Take Training Program Learning As the Starting Point to Carry out Cultivation Process Education}

Training program is a guiding document for postgraduate's cultivation process. It is not only a concrete embodiment of training objectives and quality requirements of postgraduates, but also an important basis to guide postgraduates to formulate personal training plan and to carry out standardized management for postgraduates. Learning training program not only can help the freshmen to understand the characteristics of the major and current social demand, discipline construction of universities and development status, and the professional teacher condition of colleges, but also can make the freshmen determine the research object and development direction. It can stimulate freshmen's internal drive and learning interest, cultivate creative inspiration and scientific research potential for them, and stimulate the enthusiasm of students to love professional career.

Carrying out cultivation process education in the first week of postgraduate registration can help the group of postgraduates to understand the diversified training objective, flexible period of schooling, interdisciplinary course content, advanced teaching content and interactive teaching method of the postgraduate education, and they can determine their training plan and exert individual subjective initiative according to their knowledge background and hobby. Finally, the cultivation process education can cultivate postgraduate's academic creativity, develop their special and novel mode of thinking and encourage them to explore the terra incognita with persistence.

\section{Take the Rules and Regulations As the Criterion to Carry out Culture Formative Education}

Formative education, in essence, is a kind of educational training which guides right behavioral modes and cultivates good behavioral habits. It starts from behavior training, comprehensively applies many educational methods, enhances children's quality roundly, and makes the children form good habits, including the habits of conducting himself and doing things, behavioral habits, language habits, thinking habits and so on. Formative education is a long-term and systematic project. We must apply scientific methods, follow the individual growth characteristics and psychological cognition law, cultivate the students gradually.[4]
It is one of the contents and objectives of talent cultivation of colleges and universities to carry out culture formative education for the group of postgraduates. Regard formative education as the working regulation in entrance stage, lead freshmen to learn various codes of conduct and rules and regulations of the universities, fully mobilize the initiative of students, cultivate freshmen's good habits and behaviors, and guide freshmen to establish correct outlook on life and values so as to create perfect personality and improve their selfqualities. Implement culture formative principle, cultivate postgraduate's daily habit of getting up early, early learning habit, practical behavioral habit, systematic habit of handling affairs, subjectivity of thinking habit. Guide postgraduates to cultivate perfect personality, promote postgraduate's selforganizing and conscious activity and strengthen the effectiveness of moral education of universities.

\section{Take the Model As An Example to Carry out Humanistic Motivational Education}

Humanistic motivational education is a kind of education that makes students generate life self-awareness in their growth process and let students grow with the help of their own strength by stimulating and awakening students' internal drive, moreover, its purpose is to enhance the life realm, build ideal personality and achieve the personal value and social value. The ultimate goal of humanistic motivational education is to help students to grow and succeed, realize their goals and serve the society through extensive cultural knowledge nourishment, elegant cultural atmosphere, excellent cultural tradition and profound life practical experience.[5]

The lofty value of following model and noble ideological level and moral sentiments under this value orientation will make freshmen produce great spiritual motivation. Each department can propagandize the excellent deeds of various models and examples and carry out imperceptible humanistic motivational education for the group of postgraduates by organizing summer social practice summary report, postgraduate scholarship award-giving meeting, honorary title commendation conference and "course of growth" report and other activities, so as to cultivate their anti-frustration ability and motivational inspirit. In virtue of the power of example, guide students to face difficulties with correct attitude, help them to conquer inferiority complex and make them have some idea about the their growth in postgraduate stage. Guide the postgraduates to establish lofty and firm ideals and beliefs, form persistent and diligent learning attitude, shape enthusiastic spiritual temperament, pursue noble personality trait and cultivate healthy physical and psychological qualities.

\section{E. Take the Participation of Discipline Competition As the Support to Carry out Innovation and Entrepreneurship Education}

Innovation and entrepreneurship education aims at training talents with basic entrepreneurial quality and pioneering personality, and regards cultivating students' entrepreneurial sense, entrepreneurial spirit and innovation and entrepreneurship ability as main task, and carries out innovative thinking training and entrepreneurial ability exercising by stage and hierarchy. Deepen education and 
teaching reform, combines the talents cultivation, scientific research and social service closely, achieve the transformation from paying more attention to knowledge teaching to ability and quality training, strengthen the freshmen's spirit, sense and ability of innovation and entrepreneurship, and actually enhance the quality of talent cultivation.

Each department should carry out innovation and entrepreneurship education all year round. The activity should be conducted by teachers who have training experience of discipline competition for many years. They should introduce the received results from various discipline competitions to postgraduates, and emphasize and explain some concrete competition contents, such as mathematical contest in modeling, "Challenge Cup" extracurricular science and technology work competition, entrepreneurial plan competition, so as to strengthen postgraduates' innovation and entrepreneurship awareness, enhance their spirit of innovation and entrepreneurial ability, and encourage them to carry out innovation and entrepreneurship practice. In addition, it also can establish the technology-based companies with the help of competition results to promote the development of entrepreneurship with innovative results and create a good entrepreneurial climate among the group of postgraduates.

\section{CONCLUSION}

To meet the requirements of the new historical background of postgraduate entrance education, this paper takes group psychology counseling as a method, training program learning as the starting point, the rules and regulations as the criterion, the model as an example, and the participation of discipline competition as the support, probes into conventional entrance education activity scientifically, constructs the content system of postgraduate entrance education that adapts to the new era. It also provides theoretical support and practical reference for deepening the content reform of postgraduate entrance education and enhancing the result of ideological and political education for postgraduates.

\section{REFERENCES}

[1] He Ming. Analysis of Problems in Postgraduate Entrance Education and Research on its System Constructions in the New Era[C]. // 2nd International Conference on Humanities and Social Science Research.2016:419-422.

[2] He Ming. the Exploration and Practice of Multi-Subject Implementation Mode in Postgraduate Entrance Education[C]. // 3rd International Conference on Education, Language, Art and Inter-Cultural Communication.2017:241-244.

[3] Silong Zeng. Research on the Advantages and Application of Group Psychology Counseling in Ideological and Political Education of University Students[J]. Journal of Higher Education, 2015,(4):85-86.

[4] Cheng Like. How to Effectively Play the Role of Culture Education in Students' Quality Cultivation Education[J]. Time Education, 2016 (20):85-83.

[5] Xia Guisong. Reflection and Practice of Humanistic Care in Graduate Education in Engineering[J]. Journal of Higher Education, 2015 (20): 34. 